\title{
Treatment Patterns, Disease Burden, and Outcomes in Patients with Giant Cell Arteritis and Polymyalgia Rheumatica: A Real-World, Electronic Health Record- Based Study of Patients in Clinical Practice
}

\author{
Gary Craig · Keith Knapp · Bob Salim • Shalini V. Mohan • \\ Margaret Michalska
}

Received: November 24, 2020 / Accepted: February 10, 2021 / Published online: February 26, 2021

(C) The Author(s) 2021

\section{ABSTRACT}

Introduction: Because of the chronic nature of giant cell arteritis (GCA) and/or polymyalgia rheumatica (PMR), patients may require continued glucocorticoid treatment to achieve treatment targets or prevent disease relapse, resulting in high cumulative doses. This study evaluated patterns of glucocorticoid use and outcomes in patients with GCA, PMR, or both. Methods: This retrospective study used electronic medical records from a US rheumatology clinic utilizing the JointMan ${ }^{\circledR}$ (Discus Analytics, LLC) rheumatology software. Patients aged $\geq 50$ years with a diagnosis of GCA or PMR and $\geq 1$ entry for a glucocorticoid prescription after diagnosis were included. Outcomes at 2 years after glucocorticoid initiation included the proportion of patients discontinuing

Supplementary Information The online version contains supplementary material available at https:// doi.org/10.1007/s40744-021-00290-3.

G. Craig ( $\square)$

Arthritis Northwest, PLLC, Spokane, WA, USA

e-mail: gcraig@arthritisnw.com

G. Craig · K. Knapp

Discus Analytics, LLC, Spokane, WA, USA

B. Salim

Axio Research, LLC, Seattle, WA, USA

S. V. Mohan · M. Michalska

Genentech, Inc., South San Francisco, CA, USA glucocorticoids for $\geq 6$ months, proportion of patients discontinuing glucocorticoids for $\geq 6$ months and remaining off glucocorticoids at 2 years, time to discontinuation of glucocorticoids for $\geq 6$ months, and prednisone dose and were compared between patients with GCA only, PMR only, or GCA and PMR.

Results: At 2 years after the initiation of glucocorticoids, $32 \%$ of patients $(26 / 91)$ with GCA, $32 \%(248 / 779)$ with PMR, and 27\% (26/97) with GCA and PMR discontinued glucocorticoids for $\geq 6$ months; 17,23 , and $18 \%$ discontinued glucocorticoids for $\geq 6$ months and remained off glucocorticoids at 2 years, respectively. Median (range) time to discontinuation of glucocorticoids for $\geq 6$ months was 202.5 (0-635) days and shorter in patients with both GCA and PMR vs. GCA or PMR only. The majority of patients required daily prednisone at 2 years, with similar doses observed between groups.

Conclusions: Fewer than one-third of patients with GCA and/or PMR discontinued glucocorticoids for $\geq 6$ months; the majority of patients required prednisone therapy for $\geq 2$ years after its initiation. These data highlight the need for the use of more efficacious and glucocorticoidsparing therapies in patients with GCA and/or PMR.

Keywords: Giant cell arteritis; Glucocorticoid; Polymyalgia rheumatica; Real-world data; Remission 


\section{Key Summary Points}

\section{Why carry out this study?}

For patients with giant cell arteritis (GCA) and/or polymyalgia rheumatica (PMR), glucocorticoids are the mainstay of treatment; however, tapering protocols have varied across studies and guidelines.

Due to the chronic nature of GCA and PMR, patients may require continued glucocorticoid treatment to achieve treatment goals or prevent disease relapse; over time, this can result in high cumulative doses and associated adverse events.

Using electronic medical records, this study assessed patterns of real-world glucocorticoid use and outcomes in patients with GCA, PMR, or both in a community-based practice setting.

\section{What was learned from the study?}

In a large community rheumatology practice, more than two-thirds of patients with GCA and/or PMR were unable to discontinue glucocorticoids for $\geq 6$ months and were still receiving prednisone therapy at 2 years after its initiation.

Results of this study highlight the need for the use of more efficacious and glucocorticoid-sparing therapies in patients with GCA and/or PMR.

\section{DIGITAL FEATURES}

This article is published with digital features, including a summary slide, to facilitate understanding of the article. To view digital features for this article, go to https://doi.org/10.6084/ m9.figshare.13808606.

\section{INTRODUCTION}

Giant cell arteritis (GCA) and polymyalgia rheumatica (PMR) are related and overlapping inflammatory diseases in adults aged $\geq 50$ years that have similar epidemiological distribution and overlapping clinical features. GCA often presents with cranial symptoms, such as headache, jaw claudication, and visual disturbances, including vision loss; however, some patients with GCA have general, nonspecific findings of fatigue, fever, and weight loss without cranial symptoms [1, 2]. Symptoms of PMR include severe pain and stiffness in the shoulders and sometimes neck and, less commonly, pelvic girdle pain; patients with PMR also have morning stiffness, functional impairment, and nonspecific fatigue and malaise [3].

GCA is the most common primary systemic vasculitis, and the lifetime risk is $1.0 \%$ for women and $0.5 \%$ for men aged $>50$ years [4]. For PMR, the lifetime risk is $2.4 \%$ for women and $1.7 \%$ for men [4]. The risk of developing GCA and PMR increases with age, with the highest risk occurring between the ages 70 and 79 years [4-9]. PMR is observed in approximately $40-60 \%$ of patients with GCA, and $16-21 \%$ of patients with PMR also have GCA [10].

For patients with GCA and/or PMR, glucocorticoids are the mainstay of treatment. High doses of glucocorticoids (40-60 mg/day of prednisone or equivalent) are initiated in patients with GCA to provide prompt symptom relief and prevent permanent visual loss [11]. In patients with visual symptoms, initial treatment with intravenous methylprednisolone (1000 mg/day for 3 days) followed by 3-4 weeks of oral prednisone $(80-100 \mathrm{mg} /$ day $)$ is recommended [11-13]. For patients with PMR, initial treatment is prednisone $12-25 \mathrm{mg} /$ day according to the current consensus-based recommendations [14]. Tapering of glucocorticoids is recommended once a patient with GCA no longer has clinical signs and symptoms and achieves normal levels of acute-phase reactants $[11,15]$. However, due to the chronic nature of these diseases, patients may require continued glucocorticoid treatment to achieve treatment 
goals or prevent disease relapse; over time, this can result in high cumulative doses and associated adverse events (AEs) [16-18]. Patients and treating physicians consider weight gain, cardiometabolic complications, psychological effects, osteoporosis, and infections to be the most worrisome AEs related to glucocorticoids [19].

There is a lack of data regarding the most appropriate glucocorticoid tapering regimen for patients with GCA and/or PMR, and tapering protocols have varied across studies and guidelines [20, 21]; however, according to current guidelines, the expectation is that patients will eventually either discontinue glucocorticoids or reach a dose of $\leq 5 \mathrm{mg} /$ day after 1 year $[11,14]$. In addition, among some rheumatologists in clinical practice, a common understanding based on previous teachings is that GCA often resolves within 2 years $[22,23]$.

The objective of this study was to assess patterns of real-world glucocorticoid use and outcomes in patients with GCA, PMR, or both in a community-based practice setting.

\section{METHODS}

\section{Study Design and Patients}

This retrospective cohort study used electronic medical records from a single US communitybased rheumatology clinic using the JointMan ${ }^{\circledR}$ rheumatology software application (Discus Analytics, LLC, Spokane, WA, USA). JointMan contains a combination of physician-reported data, patient-reported outcomes, and data transferred from an electronic health record (EHR) system. The physician-assigned diagnosis codes in the EHR at each encounter are transferred over to JointMan, which maintains the earliest diagnosis date for chronic conditions. Similar to the diagnosis codes, the medication and laboratory histories are also transferred over automatically from the EHR. Specifically, GCArelated diagnosis codes (ICD-9: 446.5 and ICD10: M31.6) and PMR codes (725 and L35.3) are each mapped to their respective JointMan diagnosis identifier. As medication records are received from the EHR system, the National
Drug Code (NDC), RxNorm, or SNOMED identifier is stored in JointMan along with relevant prescription and stop dates. All adult patients (at the time of first diagnosis) from the data set having the diagnosis codes (described above) and a history of glucocorticoid prescriptions were extracted from the database.

This large rheumatology clinic comprises an average of six rheumatologists and 3-4 nurse practitioners/physician assistants providing patient care during the study period. Patients aged $\geq 50$ years with a diagnosis of either GCA (based on temporal artery biopsy results or a combination of either erythrocyte sedimentation rate [ESR] or C-reactive protein [CRP] elevations and clinical manifestations, including jaw claudication, vision loss, temporal artery enlargement and tenderness) or PMR (based on development of classic proximal myalgias with morning stiffness associated with ESR and/or CRP elevation in the absence of other diagnosable inflammatory joint diseases in patients $>60$ years who subsequently had substantial rapid symptom resolution with use of glucocorticoids) and $\geq 1$ entry for a glucocorticoid prescription following the diagnosis were included. The index date was defined as the date of the first glucocorticoid prescription received at the time of GCA or PMR diagnosis.

The subgroups in this study were patients with GCA only, patients with PMR only, and patients with both GCA and PMR. If a patient's records contained multiple dates of the same diagnosis, the first diagnosis date was used to determine the index date. The group of patients with both GCA and PMR included patients who were diagnosed with GCA and PMR concurrently (either the diagnosis of GCA with PMR or separate diagnoses of GCA and PMR were entered on the same date) and those diagnosed nonconcurrently (patients who were diagnosed with GCA and PMR on different dates). For patients diagnosed with GCA and PMR on different dates, the earlier date was used to determine the index date. Patients were followed up until either loss to follow-up or the end of the study period (November 30, 2017). The limited data set used in this study was fully compliant with the Health Insurance Portability and Accountability Act Regulations (45 C.F.R. 
$\S 164.514[\mathrm{e}])$, and thus the study was exempt from institutional review board monitoring. The data in this study were classified as a limited data set because (a) the data were deidentified (i.e., no direct identifiers were used), (b) the data were used for public health purposes and (c) there is a compliant data usage agreement in place. In addition, all patients provided consent electronically for their de-identified data to be used for research purposes by their provider and associates.

\section{Outcomes}

Outcomes at 2 years included the proportion of patients discontinuing glucocorticoids for $\geq 6$ months, proportion of patients discontinuing glucocorticoids for $\geq 6$ months and remaining off glucocorticoids at 2 years, time to not receiving glucocorticoids for $\geq 6$ months, and prednisone dose at follow-up. Comparisons were made between patients with GCA only, those with PMR only, and those with both GCA and PMR. Outcomes in patients with GCA only and those with both GCA and PMR were also compared between patients who received an index prednisone dose of $<60 \mathrm{mg} /$ day and those who received $\geq 60 \mathrm{mg} /$ day.

\section{Statistical Analysis}

$P$ values are reported using $F$ test (analysis of variance) for continuous variables and $\chi^{2}$ test for categorical variables across patients with GCA only, PMR only, or both GCA and PMR. SAS version 9.4 was used for the statistical analysis.

\section{RESULTS}

A total of 81 patients with GCA only, 779 with PMR only, and 97 with GCA and PMR were identified (Table 1). Mean (SD) age was 70.0 (9.1) years and $64.2 \%$ were women. Mean (SD) daily prednisone dose at the index date was 46.7 (30.9) $\mathrm{mg}$ for patients with GCA only, 20.1 (14.2) $\mathrm{mg}$ for PMR only, and 29.0 (23.4) $\mathrm{mg}$ for patients with both GCA and PMR. The earliest index date was July 17, 2006. During the 2-year follow-up, one patient in the PMR only group had a diagnosis of granulomatosis with polyangiitis (after the PMR diagnosis), and among patients with GCA only, PMR only, and GCA and PMR, two, 34, and five patients, respectively, also had a diagnosis of rheumatoid arthritis.

Two years after the index date, $32 \%$ of patients with GCA only, 32\% with PMR only, and $27 \%$ with GCA and PMR discontinued glucocorticoids for $\geq 6$ months, and 17,23 , and $18 \%$ discontinued glucocorticoids for $\geq 6$ months and remained off glucocorticoids at 2 years, respectively (Fig. 1). There were no significant differences between groups (Fig. 2). A sensitivity analysis was conducted with death as a competing risk, which also showed no significant differences between groups (Supplementary Figure S1). The overall median (range) time to discontinuation of glucocorticoids for $\geq 6$ months was 202.5 (0-635) days and was shorter for patients with both GCA and PMR (157.0 [0-619] days) vs. those with GCA (213.0 [0-577] days) or those with PMR (203.5 [0-635] days) only (Table 2). Most patients required a daily prednisone dose at 2 years, with similar doses observed between groups (Table 3).

Among patients with GCA only who received an index prednisone dose of $<60 \mathrm{mg} /$ day $\quad(n=46), \quad 33 \%$ discontinued glucocorticoids for $\geq 6$ months, and $20 \%$ discontinued glucocorticoids for $\geq 6$ months and remained off glucocorticoids at 2 years. Among those who received an index prednisone dose of $\geq 60 \mathrm{mg} /$ day $(n=35), 31 \%$ did not receive glucocorticoids for $\geq 6$ months, and $14 \%$ remained off glucocorticoids at 2 years (Table 4). Among patients with GCA and PMR who received an index prednisone dose of $<60 \mathrm{mg}$ /day $(n=86), 24 \%$ did not receive glucocorticoids for $\geq 6$ months and $16 \%$ remained off glucocorticoids at 2 years; among those who received an index prednisone dose of $\geq 60 \mathrm{mg}(n=11), 45 \%$ and $27 \%$ remained off glucocorticoids at 2 years. Median (range) time to first remission in patients with GCA only and in those with both GCA and PMR who received an index prednisone dose of $<60 \mathrm{mg}$ was 158 (0-577) and 140 (0-619) days, respectively 
Table 1 Demographic and clinical characteristics at index date

\begin{tabular}{|c|c|c|c|c|c|}
\hline Characteristic & $\begin{array}{l}\text { GCA only } \\
(n=81)\end{array}$ & $\begin{array}{l}\text { PMR only } \\
(n=779)\end{array}$ & $\begin{array}{l}\text { GCA and PMR } \\
(n=97)\end{array}$ & $\begin{array}{l}\text { Total } \\
(N=957)\end{array}$ & $P$ value \\
\hline Age, mean (SD), years & $72.3(9.3)$ & $69.5(9.1)$ & $72.0(8.3)$ & $70.0(9.1)$ & 0.0017 \\
\hline Female, $n(\%)$ & $68(84.0)$ & $471(60.5)$ & $75(77.3)$ & $614(64.2)$ & $<0.0001$ \\
\hline \multicolumn{6}{|l|}{ Race, $n(\%)$} \\
\hline Asian & $0(0.0)$ & $2(0.4)$ & $0(0.0)$ & $2(0.3)$ & \\
\hline $\begin{array}{l}\text { American Indian or } \\
\text { Alaska Native }\end{array}$ & $1(1.8)$ & $2(0.4)$ & $0(0.0)$ & $3(0.5)$ & \\
\hline White & $44(80.0)$ & $434(89.1)$ & $56(91.8)$ & $534(88.6)$ & \\
\hline Other & $0(0.0)$ & $2(0.4)$ & $0(0.0)$ & $2(0.3)$ & \\
\hline $\begin{array}{l}\text { Not reported or } \\
\text { declined to specify }\end{array}$ & $10(18.2)$ & $47(9.7)$ & $5(8.2)$ & $62(10.3)$ & \\
\hline \multicolumn{6}{|l|}{ Weight, lbs } \\
\hline Mean (SD) & $162.9(44.4)$ & $182.6(41.7)$ & $168.8(43.1)$ & $179.7(42.5)$ & 0.0002 \\
\hline Median (range) & $161(92.4-289.0)$ & $177(84.0-431.5)$ & $157(100.0-293.8)$ & $174(84.0-431.5)$ & \\
\hline \multicolumn{6}{|l|}{$\begin{array}{l}\text { Prednisone dose, } \\
\text { mg/day }\end{array}$} \\
\hline Mean (SD) & $46.7(30.9)$ & $20.1(14.2)$ & $29.0(23.4)$ & $23.2(18.9)$ & $<0.0001$ \\
\hline Median (range) & $44(0-150)$ & $20(0-99)$ & $24(0-105)$ & $20(0-150)$ & \\
\hline $\begin{array}{l}\text { Temporal headache, } \\
n(\%)\end{array}$ & $30(45.5)$ & $99(19.1)$ & $30(54.5)$ & $159(24.9)$ & $<0.0001$ \\
\hline Jaw claudication, $n(\%)$ & $1(1.5)$ & $1(0.2)$ & $1(1.8)$ & $3(0.5)$ & 0.1037 \\
\hline Visual loss, $n(\%)$ & $8(12.1)$ & $10(1.9)$ & $11(20.0)$ & $29(4.5)$ & $<0.0001$ \\
\hline
\end{tabular}

$G C A$ giant cell arteritis, $P M R$ polymyalgia rheumatica, $S D$ standard deviation

a Percentages are based on the number of patients with data available

(Table 4). Among patients with GCA only and in those with both GCA and PMR who received an index prednisone dose of $\geq 60 \mathrm{mg}$, median (range) time to first remission was 271 (0-363) and 255 (0-491) days, respectively.

\section{DISCUSSION}

At the 2-year follow-up of this study, fewer than one-third of patients with GCA and/or PMR had discontinued glucocorticoids for $\geq 6$ months, with no significant differences observed between patients with GCA only, PMR only, or GCA and PMR. These low rates of glucocorticoid discontinuation for $\geq 6$ months were lower than expected. One possible reason for this is the potential differences between patients with and those without large-vessel involvement. Although long-term data comparing patients with GCA with and without large-vessel involvement are limited, some studies have suggested that patients with large-vessel involvement have more refractory disease [24-26]. In the present study, patients with GCA were diagnosed based on temporal artery biopsy 


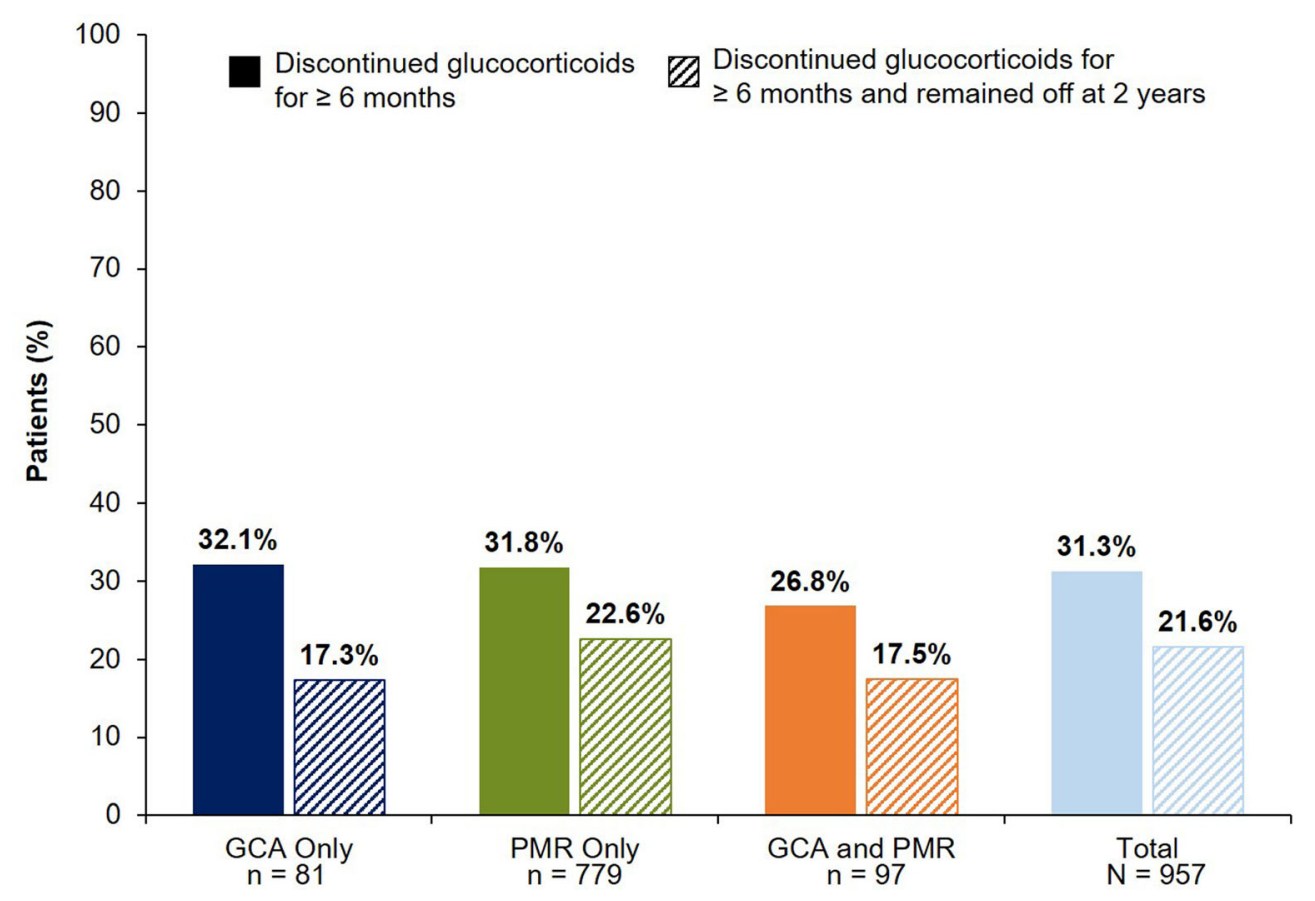

Fig. 1 At 2 years after the index date, the proportion of patients who discontinued glucocorticoids for $\geq 6$ months and proportion of patients who discontinued

glucocorticoids for $\geq 6$ months and remained off at the 2-year follow-up. $G C A$ giant cell arteritis, PMR polymyalgia rheumatica

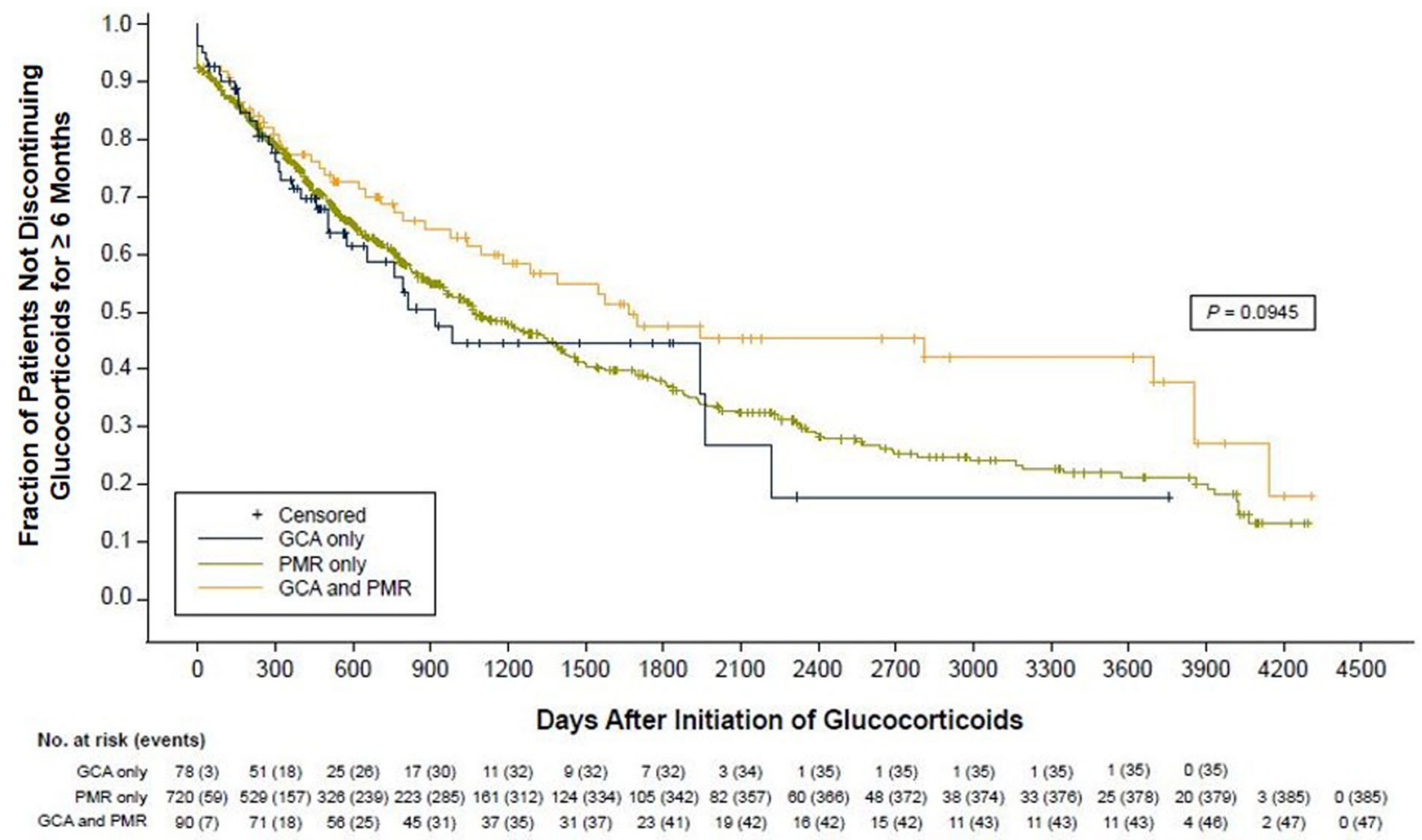

Fig. 2 Time to discontinuation of glucocorticoids for $\geq 6$ months. $G C A$ giant cell arteritis, PMR polymyalgia rheumatica 
Table 2 Time to discontinuation of glucocorticoids for $\geq 6$ months within 2 years of follow-up

\begin{tabular}{|c|c|c|c|c|c|}
\hline & $\begin{array}{l}\text { GCA only } \\
(n=81)\end{array}$ & $\begin{array}{l}\text { PMR only } \\
(n=779)\end{array}$ & $\begin{array}{l}\text { GCA and } \\
\text { PMR } \\
(n=97)\end{array}$ & $\begin{array}{l}\text { Total } \\
(N=957)\end{array}$ & $P$ value \\
\hline $\begin{array}{l}\text { Patients who discontinued glucocorticoids } \\
\text { for } \geq 6 \text { months, } n(\%)^{\mathrm{a}}\end{array}$ & $26(32.1)$ & $248(31.8)$ & $26(26.8)$ & $300(31.3)$ & \\
\hline \multicolumn{6}{|c|}{ Time to discontinuation of glucocorticoids for $\geq 6$ months, days } \\
\hline Mean (SD) & $224.3(171.7)$ & $226.5(198.6)$ & $208.4(186.6)$ & $224.7(194.9)$ & 0.014 \\
\hline Median (range) & $213.0(0-577)$ & $203.5(0-635)$ & $157.0(0-619)$ & $202.5(0-635)$ & \\
\hline
\end{tabular}

$G C A$ giant cell arteritis, $P M R$ polymyalgia rheumatica, $S D$ standard deviation

Table 3 Prednisone dose at 2 years after the index date

\begin{tabular}{|c|c|c|c|c|c|}
\hline & $\begin{array}{l}\text { GCA } \\
\text { only } \\
(n=81)\end{array}$ & $\begin{array}{l}\text { PMR } \\
\text { only } \\
(n=779)\end{array}$ & $\begin{array}{l}\text { GCA and } \\
\text { PMR } \\
(n=97)\end{array}$ & $\begin{array}{l}\text { Total } \\
(N=957)\end{array}$ & $P$ value \\
\hline $\begin{array}{l}\text { Patients who had prednisone dose information available at } \\
2 \text { years, } n\end{array}$ & 26 & 341 & 60 & 427 & \\
\hline \multicolumn{6}{|l|}{ Prednisone dose, mg/day } \\
\hline Mean (SD) & $9.5(10.6)$ & $8.8(9.2)$ & $12.6(15.9)$ & $9.4(10.5)$ & 0.0819 \\
\hline Median (range) & $5(0-40)$ & $5(0-66)$ & $7.5(0-80)$ & $5(0-80)$ & \\
\hline
\end{tabular}

$G C A$ giant cell arteritis, $P M R$ polymyalgia rheumatica, $S D$ standard deviation

or laboratory results in combination with cranial clinical manifestations; however, as large-vessel imaging is not currently standard practice, it is possible that these patients had large-vessel involvement. There are currently no standard recommendations for large-vessel imaging in patients with GCA, but performing baseline aortic imaging at the time of diagnosis has been recommended [27, 28]. Screening patients with PMR for large-vessel inflammation has also been suggested [2].

The overall median time to discontinuing glucocorticoids for $\geq 6$ months was shorter in patients with both GCA and PMR than in those with GCA only or PMR only. Notably, more than two-thirds of patients with GCA and/or PMR did not discontinue glucocorticoids for $\geq 6$ months and were still receiving prednisone therapy 2 years after its initiation, leading to exposure to substantial cumulative doses of glucocorticoids. These results suggest that in a large, multiple-provider community practice, patient exposure to ongoing glucocorticoid therapy was longer than generally anticipated on the basis of teachings in previous textbooks $[22,23]$. However, results of the present study are consistent with those reported in a study of patients with GCA and/or PMR followed up in rheumatology clinics in Germany [29]; additionally, another retrospective cohort study reported that patients with GCA received glucocorticoids for a median of 2.6 years [30]. Furthermore, a retrospective cohort study of patients with PMR showed the median time to discontinuation of GCs was 5.95 years, and the time to reach $<5 \mathrm{mg} /$ day for 6 months was 1.44 years [31].

Among patients with GCA or both GCA and PMR, most did not discontinue glucocorticoids for $\geq 6$ months whether results were stratified 
Table 4 Discontinuation of glucocorticoids for $\geq 6$ months (at 2 years after the index date) by index prednisone dose

\begin{tabular}{|c|c|c|c|c|}
\hline & \multicolumn{2}{|l|}{ GCA only } & \multicolumn{2}{|c|}{ GCA and PMR } \\
\hline & $\begin{array}{l}\text { Index dose } \\
<60 \mathrm{mg} / \text { day } \\
(n=46)\end{array}$ & $\begin{array}{l}\text { Index dose } \\
\geq 60 \mathrm{mg} / \text { day } \\
(n=35)\end{array}$ & $\begin{array}{l}\text { Index dose } \\
<60 \mathrm{mg} / \text { day } \\
(n=86)\end{array}$ & $\begin{array}{l}\text { Index dose } \\
\geq 60 \mathrm{mg} / \text { day } \\
(n=11)\end{array}$ \\
\hline \multicolumn{5}{|l|}{ Index prednisone dose, $\mathrm{mg} /$ day } \\
\hline Mean (SD) & $24.5(14.2)$ & $75.9(20.8)$ & $22.7(15.3)$ & $77.7(17.9)$ \\
\hline Median (range) & $22.5(0-55)$ & $70(60-150)$ & $20(0-58)$ & $80(60-105)$ \\
\hline $\begin{array}{l}\text { Patients who discontinued glucocorticoids } \\
\text { for } \geq 6 \text { months, } n \text { (\%) }\end{array}$ & $15(32.6)$ & $11(31.4)$ & $21(24.4)$ & $5(45.5)$ \\
\hline \multicolumn{5}{|l|}{$\begin{array}{l}\text { Time from index prednisone dose to discontinuation } \\
\text { of glucocorticoids for } \geq 6 \text { months, days }\end{array}$} \\
\hline Mean (SD) & $223.7(206.0)$ & $225.2(119.6)$ & $207.5(185.7)$ & $212.2(212.2)$ \\
\hline Median (range) & $158(0-577)$ & $271(0-363)$ & $140(0-619)$ & $255(0-491)$ \\
\hline $\begin{array}{l}\text { Patients who discontinued glucocorticoids } \\
\text { for } \geq 6 \text { months and remained off at } 2 \text { years, } n \text { (\%) }\end{array}$ & $9(19.6)$ & $5(14.3)$ & $14(16.3)$ & $3(27.3)$ \\
\hline
\end{tabular}

$G C A$ giant cell arteritis, $P M R$ polymyalgia rheumatica, $S D$ standard deviation

according to index prednisone dose of $<60$ or $\geq 60 \mathrm{mg} /$ day. Although some patient groups were small, these results provide further support that most patients in this community practice who received prednisone to treat GCA or both GCA and PMR were unable to discontinue glucocorticoids for $\geq 6$ months regardless of the initial prednisone dose.

The median starting dose of glucocorticoids in patients with GCA was similar to starting doses previously described in other real-world studies of patients with GCA [16, 18, 32] and was consistent with treatment guidelines [11]. At the 2-year follow-up, the median dose of prednisone was similar between patients with GCA only, those with PMR only, and those with both GCA and PMR; however, doses as high as $80 \mathrm{mg} /$ day were reported in patients with GCA and PMR. Notably, doses as high as $66 \mathrm{mg} /$ day were reported in patients with PMR only.

Even at low doses, continued, daily exposure to prednisone can lead to high cumulative doses and AEs. A real-world study of US and UK claims data reported a significantly greater risk of developing glucocorticoid-related AEs with each additional $1 \mathrm{~g}$ of cumulative glucocorticoid exposure (over the first year after diagnosis and the full follow-up) [16]. In addition, rates of potential glucocorticoid-related AEs have been shown to increase with an increase in cumulative glucocorticoid dose, which resulted in higher healthcare costs [33].

Decreasing the risk of glucocorticoid-related AEs is crucial because patients with GCA and/or PMR are older and often have comorbidities at the time of diagnosis and treatment initiation [34]. Because of the AEs associated with longterm glucocorticoids, guidelines recommend that early initiation of steroid-sparing agents be considered for patients with GCA and/or PMR $[11,14,15]$. Two randomized controlled trials in patients with GCA have demonstrated that treatment with either subcutaneous or intravenous tocilizumab is more effective at inducing relapse and decreases cumulative glucocorticoid exposure compared with glucocorticoids alone [35, 36]. In addition, a higher rate of serious AEs was seen in the placebo + prednisone groups than in the tocilizumab + prednisone groups [35, 36]. Results from prospective, open-label trials suggest that tocilizumab may be effective for the treatment of PMR [37-39]. 
Because of the nature of retrospective, observational studies, this study has some limitations. Patients were from a single multipleprovider US community rheumatology clinic, and results may not reflect those in other geographic areas. The exact dates of when some patients initiated glucocorticoids were not available as a result of a tentative diagnosis of GCA and/or PMR by the referring physician. Information on prednisone dose was not available for all patients at 2 years after the index date. In addition, when data were analyzed according to index prednisone dose, some patient groups were relatively small. As the focus of this study was prednisone use, information about adjunctive therapies or steroidsparing agents was not available, nor were data on cumulative glucocorticoid doses. Despite these limitations, this real-world study of patients in clinical practice provides important information on use of prednisone and outcomes in patients with GCA and/or PMR.

\section{CONCLUSIONS}

More than two-thirds of patients with GCA and/ or PMR in this study were unable to discontinue glucocorticoids for $\geq 6$ months and were still receiving prednisone therapy 2 years after its initiation. The higher-than-anticipated number of patients with continued disease and exposure to glucocorticoids at 2 years suggests a more chronic nature of GCA and PMR in this realworld study rather than the existing expectation that GCA and PMR often resolve within 2 years of therapy. These results highlight the need to consider a potential long-term disease course in patients with GCA and/or PMR and for the use of efficacious, glucocorticoid-sparing therapies in these patients.

\section{ACKNOWLEDGEMENTS}

Funding. This study was funded by Genentech, Inc (South San Francisco, CA, USA). This study was conceived by authors at Genentech, Inc., in collaboration with the other authors.
This article was reviewed and approved for publication by Genentech, Inc. the journal's Rapid Service fee was funded by Genentech, Inc.

Medical Writing Assistance. Third-party writing assistance, furnished by Nicola Gillespie, DVM, of Health Interactions, Inc, was funded by Genentech, Inc.

Authorship. All named authors meet the International Committee of Medical Journal Editors (ICMJE) criteria for authorship for this article, take responsibility for the integrity of the work as a whole, and have given their approval for this version to be published.

Prior Presentation. A portion of these data was presented at the 2019 EULAR Annual European Congress of Rheumatology, June 12-15, Madrid, Spain, and at the 2019 ACR Annual Meeting, November 8-13, Atlanta, GA, USA.

Disclosures. Gary Craig is co-owner of Arthritis Northwest, PLLC, and Discus Analytics, LLC, and has served on an advisory board for Premera Blue Cross and on speakers bureaus for Bristol Myers Squibb, Eli Lilly, Genentech, Celgene, AbbVie, Novartis, and Sandoz. Keith Knapp was an employee of Discus Analytics, LLC, at the time of the study and manuscript preparation and has served as a consultant for Bristol Myers Squibb. Bob Salim is an employee of Axio Research, LLC. Margaret Michalska and Shalini Mohan are employees and shareholders of Genentech, Inc.

Compliance with Ethics Guidelines. The limited data set used in this study was fully compliant with the Health Insurance Portability and Accountability Act Regulations (45 C.F.R. $\$ 164.514[\mathrm{e}])$, and thus the study was exempt from institutional review board monitoring. The data in this study were classified as a limited data set because (a) the data were deidentified (i.e., no direct identifiers were used), (b) the data were used for public health purposes and (c) there is a compliant data usage agreement in place. In addition, all patients provided consent electronically for their de-identified data to be 
used for research purposes by their provider and associates.

Data Availability. The datasets analyzed during the current study are not publicly available because they are the proprietary property of Discus Analytics.

Open Access. This article is licensed under a Creative Commons Attribution-NonCommercial 4.0 International License, which permits any non-commercial use, sharing, adaptation, distribution and reproduction in any medium or format, as long as you give appropriate credit to the original author(s) and the source, provide a link to the Creative Commons licence, and indicate if changes were made. The images or other third party material in this article are included in the article's Creative Commons licence, unless indicated otherwise in a credit line to the material. If material is not included in the article's Creative Commons licence and your intended use is not permitted by statutory regulation or exceeds the permitted use, you will need to obtain permission directly from the copyright holder. To view a copy of this licence, visit http://creativecommons.org/licenses/bync/4.0/.

\section{REFERENCES}

1. Nesher G. The diagnosis and classification of giant cell arteritis. J Autoimmun. 2014;8-49:73-5.

2. Gonzalez-Gay MA, Ortego-Jurado M, Ercole L, Ortego-Centeno N. Giant cell arteritis: is the clinical spectrum of the disease changing? BMC Geriatr. 2019;19(1):200.

3. Gonzalez-Gay MA, Matteson EL, Castaneda S. Polymyalgia rheumatica. Lancet. 2017;7(390): 1700-12.

4. Crowson CS, Matteson EL, Myasoedova E, et al. The lifetime risk of adult-onset rheumatoid arthritis and other inflammatory autoimmune rheumatic diseases. Arthritis Rheum. 2011;63(3):633-9.

5. Doran MF, Crowson CS, O'Fallon WM, Hunder GG, Gabriel SE. Trends in the incidence of polymyalgia rheumatica over a 30-year period in Olmsted
County, Minnesota, USA. J Rheumatol. 2002;29(8): 1694-7.

6. Brekke LK, Diamantopoulos AP, Fevang BT, Abetamus J, Espero E, Gjesdal CG. Incidence of giant cell arteritis in Western Norway 1972-2012: a retrospective cohort study. Arthritis Res Ther. 2017;19(1):278

7. Petri H, Nevitt A, Sarsour K, Napalkov P, Collinson $\mathrm{N}$. Incidence of giant cell arteritis and characteristics of patients: data-driven analysis of comorbidities. Arthritis Care Res (Hoboken). 2015;67(3): 390-5.

8. Partington RJ, Muller S, Helliwell T, Mallen CD, Abdul SA. Incidence, prevalence and treatment burden of polymyalgia rheumatica in the UK over two decades: a population-based study. Ann Rheum Dis. 2018;77(12):1750-6.

9. Gonzalez-Gay MA, Vazquez-Rodriguez TR, LopezDiaz MJ, et al. Epidemiology of giant cell arteritis and polymyalgia rheumatica. Arthritis Rheum. 2009;61(10):1454-61.

10. Buttgereit F, Dejaco C, Matteson EL, Dasgupta B. Polymyalgia rheumatica and giant cell arteritis: a systematic review. JAMA. 2016;315(22):2442-58.

11. Hellmich B, Agueda A, Monti S, et al. 2018 Update of the EULAR recommendations for the management of large vessel vasculitis. Ann Rheum Dis. 2020;79:19-30.

12. Almarzouqi SJ, Morgan ML, Lee AG. Treatment of giant cell arteritis. Curr Opin Ophthalmol. 2015;26(6):469-75.

13. Chan CC, Paine M, O'Day J. Steroid management in giant cell arteritis. Br J Ophthalmol. 2001;85(9): 1061-4.

14. Dejaco C, Singh YP, Perel P, et al. Recommendations for the management of polymyalgia rheumatica: a European League Against Rheumatism/American College of Rheumatology collaborative initiative. Ann Rheum Dis. 2015;74(10): 1799-807.

15. Dasgupta B, Borg FA, Hassan N, et al. BSR and BHPR guidelines for the management of giant cell arteritis. Rheumatology (Oxford). 2010;49(8):1594-7.

16. Gale S, Wilson JC, Chia J, et al. Risk associated with cumulative oral glucocorticoid use in patients with giant cell arteritis in real-world databases from the USA and UK. Rheumatol Ther. 2018;5:1-14.

17. Wilson JC, Sarsour K, Collinson N, et al. Serious adverse effects associated with glucocorticoid therapy in patients with giant cell arteritis (GCA): a 
nested case-control analysis. Semin Arthritis Rheum. 2017;46(6):819-27.

18. Broder MS, Sarsour K, Chang E, et al. Corticosteroid-related adverse events in patients with giant cell arteritis: a claims-based analysis. Semin Arthritis Rheum. 2016;46(2):246-52.

19. van der Goes MC, Jacobs JW, Boers M, et al. Patient and rheumatologist perspectives on glucocorticoids: an exercise to improve the implementation of the European League Against Rheumatism (EULAR) recommendations on the management of systemic glucocorticoid therapy in rheumatic diseases. Ann Rheum Dis. 2010;69(6):1015-21.

20. Monti S, Águeda AF, Luqmani RA, et al. Systematic literature review informing the 2018 update of the EULAR recommendation for the management of large vessel vasculitis: focus on giant cell arteritis. RMD Open. 2019;5(2):e001003.

21. Hellmich B, Agueda A, Monti S, et al. 2018 Update of the EULAR recommendations for the management of large vessel vasculitis. Ann Rheum Dis. 2019;79(1):19-30.

22. Hunder GC, et al. Giant cell arteritis and polymyalgia rheumatica. In: Ruddy S, HarrisSledge EDCB, et al., editors. Kelley's textbook of rheumatology. 6th ed. Philadelphia: WB Saunders and Company; 2001. p. 116223.

23. Weyand C, Goronzy J. Primer on the rheumatics diseases. In: Klippel J, Stone J, Crofford L, White P, editors. Vasculitidies. New York: Springer; 2008. p. 404 .

24. Muratore F, Kermani TA, Crowson CS, et al. Largevessel giant cell arteritis: a cohort study. Rheumatology (Oxford). 2015;54(3):463-70.

25. Espitia O, Néel A, Leux C, et al. Giant cell arteritis with or without aortitis at diagnosis. A retrospective study of 22 patients with long-term follow-up. J Rheumatol. 2012;39(11):2157-62.

26. de Boysson H, Liozon E, Ly KH, Dumont A, Delmas C, Aouba A. The different clinical patterns of giant cell arteritis. Clin Exp Rheumatol. 2019;37 Suppl 117(2):57-60.

27. Berger CT, Sommer G, Aschwanden M, Staub D, Rottenburger C, Daikeler T. The clinical benefit of imaging in the diagnosis and treatment of giant cell arteritis. Swiss Med Wkly. 2018;148:w14661.

28. Koster MJ, Matteson EL, Warrington KJ. Large-vessel giant cell arteritis: diagnosis, monitoring and management. Rheumatology (Oxford). 2018;57(Suppl-2):ii32-42.
29. Albrecht K, Huscher D, Buttgereit F, et al. Longterm glucocorticoid treatment in patients with polymyalgia rheumatica, giant cell arteritis, or both diseases: results from a national rheumatology database. Rheumatol Int. 2018;38(4):569-77.

30. Chandran A, Udayakumar PD, Kermani TA, Warrington KJ, Crowson CS, Matteson EL. Glucocorticoid usage in giant cell arteritis over six decades (1950 to 2009). Clin Exp Rheumatol. 2015;33(2 Suppl 89):S-98-102.

31. Shbeeb I, Challah D, Raheel S, Crowson CS, Matteson EL. Comparable rates of glucocorticoid-associated adverse events in patients with polymyalgia rheumatica and comorbidities in the general population. Arthritis Care Res (Hoboken). 2018;70(4): 643-7.

32. Proven A, Gabriel SE, Orces C, O'Fallon WM, Hunder GG. Glucocorticoid therapy in giant cell arteritis: duration and adverse outcomes. Arthritis Rheum. 2003;49(5):703-8.

33. Best JH, Kong A, Smith D, Abbass I, Michalska M (2018) Healthcare cost of potential glucocorticoidassociated adverse events in patients with giant cell arteritis [abstract]. Arthritis Rheumatol 70

34. Strehl C, Bijlsma JW, de Wit M, et al. Defining conditions where long-term glucocorticoid treatment has an acceptably low level of harm to facilitate implementation of existing recommendations: viewpoints from an EULAR task force. Ann Rheum Dis. 2016;75(6):952-7.

35. Stone JH, Tuckwell K, Dimonaco S, et al. Trial of tocilizumab in giant-cell arteritis. N Engl J Med. 2017;377(4):317-28.

36. Villiger PM, Adler S, Kuchen S, et al. Tocilizumab for induction and maintenance of remission in giant cell arteritis: a phase 2, randomised, doubleblind, placebo-controlled trial. Lancet. 2016;387(10031):1921-7.

37. Lally L, Forbess L, Hatzis C, Spiera R. Brief Report: A Prospective open-label phase IIa trial of tocilizumab in the treatment of polymyalgia rheumatica. Arthritis Rheumatol. 2016;68(10):2550-4.

38. Devauchelle-Pensec V, Berthelot JM, Cornec D, et al. Efficacy of first-line tocilizumab therapy in early polymyalgia rheumatica: a prospective longitudinal study. Ann Rheum Dis. 2016;75(8): 1506-10.

39. Chino K, Kondo T, Sakai R, et al. Tocilizumab monotherapy for polymyalgia rheumatica: a prospective, single-center, open-label study. Int J Rheum Dis. 2019;22(12):2151-7. 